\title{
LEXICAL UNITS REPRESENTING WORKING WOMEN IN VICTORIAN NOVELS
}

\author{
Anna Orel \\ Taras Shevchenko National University of Kyiv, Ukraine \\ annamaria@ukr.net
}

\begin{abstract}
One of the most prevalent issues of the Victorian era was the increasing movement of women into the job market. That was the time when the traditional female roles were reinforced and reconsidered at the same time. Women who were regarded as "Angels of the house" started to seek freedom from domesticity. The article explores the lexical units representing working women in Victorian novels. It highlights the major areas in which Victorian women were involved (household service, education, industry, outwork, trade, entrepreneurship, agriculture, art). The analysis is based on a number of methods, in particular on the lexical-semantic field method and the frame analysis. The socio-cultural commentary along with the extensive illustrative material enables the author to single out the lexemes describing female professions (lady's maid, housemaid, governess, schoolmistress, etc.) as well as the most common stereotypes concerning working women in those days. The contextual environment study of 33 female job titles offers insight into typical actions, social status, as well as the inner life of Victorian working women. However, the less typical female occupations (doctors, politicians, etc.) can be rarely found in Victorian novels. The findings of the analysis may be useful for linguistic and cultural research of the Victorian era as well as for gender and feminist studies.
\end{abstract}

Keywords: Victorian era; linguistic and cultural analysis; gender studies; working women; female job titles.

\section{Introduction}

The purpose of retrospective cultural studies is to investigate the influence of the culture of a certain period in the past on the formation of the cultural values of the present. In this regard, the Victorian culture is especially valuable. The interest in exploring the Victorian age by contemporary researchers is driven by the need to rethink Victorian values, their significance for the present, as well as the attempts to revive some Victorian traditions.

The Victorian era is regarded as the most dynamic time. Its dynamism manifests itself not only in social changes, political reforms, and scientific discoveries but also in the ambiguous attitude towards women. The defining features of that period are, on the one hand, the creation of stereotypes concerning women, and on the other hand, the struggle of women against those stereotypes. The conceptual expression of basic female stereotypes is the notion of "Angels of the house". Victorian woman embodied family values that were of crucial importance to Victorians. Such perception of women is interpreted in feminist studies as a restriction of female freedom: "almost all nineteenth-century women were in some sense imprisoned in men's houses" (Gilbert \& Gubar, 1984, p. 83).

This stereotypical understanding, however, may mostly apply to upper-middle class women, while remaining the dream of the lower middle-class. "To the poor housewife the angel was an ideal, a model of the gentlewoman that she aspired to become" (Peterson, 1984, p. 708). According to Priestley (1974), "many a middle-class 'lady' and the women who waited on her seemed hardly to belong to the same species. [...]. The women who kept the house clean and warm or worked sixty hours a week in the husband's factory were assumed to be as strong as horses" (p. 30).

The Victorian era was a period of some changes in the sphere of legal and social protection of working women. In 1857, the Association for the Promotion of Employment of Women was founded. In the same year, the work of Barbara Bodison "Women and Work" and of Caroline Cornwall "Capabilities and Disabilities of Women" appeared. Despite this, a working woman was rarely able to pursue a career on an equal footing with men. "The working woman was not [...] a Victorian institution. [...] To the Victorians belong the discovery of the woman worker as an object of pity, and in the literature of the early nineteenth century one first finds her portrayed as a victim of long hours, unfavourable conditions, and general injustice, for whom something ought to be done" (Neff, 1966, p. 11).

\section{Objectives and methods}

The article aims at exploring the lexical units describing working women in Victorian novels. The methods employed in the research include the lexical-semantic field method, elements of the frame analysis, developed by Zhabotynska (2010), context-situational and component analyses applied on the basis of interpretive and socio-cultural approaches. The study of the contextual environment of lexemes representing Victorian working women together with a socio-cultural commentary exposes basic stereotypes regarding female social roles of Victorian women. A total of eight novels have been analysed.

Orel, A. (2019). Lexical units representing working women in Victorian novels. Advanced Education, 12, 174-180. DOI: $10.20535 / 2410-8286.122279$ 


\section{Results and discussion}

The analysis of Victorian novels reveals the following key areas in which women worked: 1) household service; 2) education; 3) industry; 4) outwork; 5) trade, entrepreneurship; 6) agriculture; 7) art.

1. Household service. As Priestley (1974) claims, "the chief occupation of growing girls and young women was domestic service. In 1851 there were in Britain over eight million females of ten years of age and upwards - about half a million more than males - and nearly a million of them were domestic servants of one kind and another. Wages were low [...]; living conditions were often poor; and the work long and hard" (p. 25). The position of a lady's maid was much better than that of other servants, thus poor girls often dreamt of becoming a lady's maid:

'What, are you going to be a lady's-maid?' 'I should like to be one very much indeed,' Hetty spoke more audibly now (Eliot, 1994, p. 133).

She thinks there's nothing belongs to being a lady's-maid, but wearing finer clothes (Eliot, 1994, p. 324).

I'll not forget to give thee a lift now an' then when that comes about. Nay, who knows, if thou'rt a good girl, but may happen I may make thee my lady's maid! (Gaskell, 1994, p. 89).

The contextual analysis of the novels detected the following lexical units referring to female servants: outcook (Brontë, 1994, p.41), charwoman (Hardy, 1994, p.307), kitchen-maid (Thackeray, 1994, p. 385), lady's-maid (Eliot, 1994, p. 133), maid, servant-girl (Brontë, 1994, p. 23), upper-housemaid, maid-servant (Thackeray, 1994, p. 180), governess, daily governess, nurse, nurse-girl (Gaskell, 1994, p. 146).

In order to single out the typical actions that the Victorian female servant performs in the Victorian novels, we applied the frame analysis after Zhabotynska (2010). The action frame representing activities conducted by female servants covers the following:

1) Cooking and serving the meal:

[...] a [...] maid [...] appeared with the teapot (Thackeray, 1994, p. 511).

[...] the Irish maid-servant came with a plate and a bottle of wine (Thackeray, 1994, p. 243).

[...] a kitchen-maid let him in. She had a bowl of hot soup prepared for him (Meredith, 1962, p. 464).

The cook broiled steaks, and the kitchen-maid toasted bread, and boiled eggs (Gaskell, 1994, p. 62).

2) Cleaning and keeping the house:

Dolly his maid was making his bed [...] (Thackeray, 1994, p. 364).

You must let her have a maid to keep things tidy about her (Brontë E., 1994, p. 135).

3) Looking after her masters:

[...] her maid dressed her with unusual care (Thackeray, 1994, p. 630).

But this maid was very useful in the family, in dexterously tending old Mr. Sedley (Thackeray, 1994, p. 581).

[...] the maid left the kitchen to be ready to attend to the young ladies' bell when they chose to ring (Gaskell, 1994, p. 63).

In addition to the main duties, the maid was often a person whose mistress entrusted her with her secrets, asked to send letters, etc.:

A maid in the secrets of her mistress is a purchasable maid, for if she will take a bribe with her right hand she will with her left (Meredith, 1962, p. 339).

"There's a message," the maid went on. [...] And she gave her a letter, which Emmy took, and read (Thackeray, 1994, p.168).

"My maid Barclay will hand him a letter at noon" (Meredith, 1962, p. 320).

Sometimes a maid performed various duties, so there was no exact lexeme for her nomination:

It seemed that a maid, or rather companion, who had waited on her for some years, was about to be married (Bronte Ch., 1992, p.43).

It appeared my place was to be a hybrid between gouvernante and lady's-maid (Bronte Ch., 1992, p.89).

A servant, semi-upper-housemaid, semi-lady's-maid, now came down with orders from her mistress (Gaskell, 1994, p. 62).

Unlike a maid or a cook whose work did not require qualifications, the governess needed an appropriate education. Only in relation to the governess the lexemes meaning "educated" are used:

Either of these young ladies is perfectly qualified to instruct in Greek, Latin, and the rudiments of Hebrew (Thackeray, 1994, p. 88).

The position of the governess is described by with the language means, which denote the following characteristics:

1) Low social status: 
With regard to her sisters-in-law Rebecca did not attempt to forget her former position of Governess towards them, but recalled it frankly and kindly (Thackeray, 1994, p. 399).

At least she gives herself no airs, and remembers that she was our Governess once, Miss Violet said, intimating that it befitted all governesses to keep their proper place (Thackeray, 1994, p. 399).

2) Limited financial capabilities:

"I don't trust them governesses, Pinner, she remarked to the maid. They give themselves the hairs and hupstarts of ladies, and their wages is no better than you nor me (Thackeray, 1994, p. 55).

3) Psychological discomfort due to the lack of her own family life and children:

[...] a few miserable governesses with wan-faced pupils wandering round and round it, and round the dreary grass-plot (Thackeray, 1994, p. 450).

Inadventurous, unstirred by impulses of practical ambition, I was capable of sitting twenty years teaching infants the hornbook, turning silk dresses and making children's frocks (Bronte Ch., 1992, p. 100).

[...] his electrically forethoughtful mind had seen in Miss Dale, if she stayed in the neighbourhood, and remained unmarried, the governess of his infant children, often consulting with him (Meredith, 1962, p. 116).

4) Limited possibilities to realise her talents and skills:

[...] rich baronets do not need to be careful about grammar, as poor governesses must be (Thackeray, 1994, p. 65).

In 1841, the Governesses' Benevolent Institution was founded, and in 1846 A. Jameson wrote her essay On the Relative Social Position of Mothers and Governesses. Despite these steps, the governess's work practically did not give the girl the opportunities for career growth.

Thus, the semantic field representing household service contains typical feminine job titles. The word "maid" prevails as a separate lexeme or as a part of compound words (lady's-maid, housemaid, etc.). The action frame contains the traditional duties of female servants which range from keeping the house to being companions of their mistresses. The contextual analysis of lexemes representing governess' duties reveals mostly derogatory adjectives (inadventurous, miserable, poor, etc).

2. Education. The Victorian era was the time when female education became a critical issue. It was considered in the works by J. Butler (The Education and Employment of Women, 1868), B. Parkes (Remarks on the Education of Girls,1856), E. Shirreff (Intellectual Education and Its Influence on the Character and Happiness of Women, 1856), etc. In 1848 the first higher education college for women, Queen's College was founded. It provided training for governesses and schoolteachers.

The lexemes referring to female teachers in the novels are mostly schoolmistress and teacher. The contextual analysis of the lexeme schoolmistress showed that it possesses the following stereotypical characteristics:

- vanity:

[...] Miss Pinkerton herself, that majestic lady; the Semiramis of Hammersmith (Thackeray, 1994, p. 1).

Worthy Miss Pinkerton, although she had a Roman nose and a turban, and was as tall as a grenadier, and had been up to this time an irresistible princess (Thackeray, 1994, p. 12).

The pompous vanity of the old schoolmistress (Thackeray, 1994, p. 11).

- snobbish attitude to poor students:

For two years I have only had insults and outrage from her. I have been treated worse than any servant in the kitchen (Thackeray, 1994, p. 8).

- low level of education compared to teachers and even pupils:

Miss Pinkerton did not understand French; she only directed those who did (Thackeray, 1994, p. 6).

Lexemes that describe schools for girls mean "academism", "restraint":

The rigid formality of the place suffocated her: the prayers and the meals, the lessons and the walks, which were arranged with a conventual regularity (Thackeray, 1994, p. 11).

[...] the frigid correctness of the governesses equally annoyed her (Thackeray, 1994, p. 11).

The main typical qualities of an English teacher are given in the novel "Jane Eyre":

I was still looking at them, and also at intervals examining the teachers - none of whom precisely pleased me; for the stout one was a little coarse, the dark one not a little fierce, the foreigner harsh and grotesque, and Miss Miller, poor thing! looked purple, weather-beaten, and over-worked (Brontë, 1994, p. 49).

Summarising the mentioned above, the lexemes describing women in education reveal Victorian stereotypes on schoolmistresses (pompous, frigid) and female teachers (weather-beaten, over-worked). Such 
a limited range of descriptive adjectives indicates the oppression of patriarchal society where the role of Victorian female teachers was restricted to educating "Angels of the house".

3. Industry. The Victorian era was the epoch of the Industrial Revolution. Due to the lack of social protection, women had to work twelve hours a day. In 1842 Ashely's Mines Act forbade the employment of women in the mines. In 1847 the working hours of women were restricted to 10 hours a day. Despite these measures, women continued to suffer from exploitation and gender inequality, since their wages were lower than those of men's:

That's the worst of factory work for girls. They can earn so much when work is plenty, that they can maintain themselves any how (Gaskell, 1994, p. 7).

Most women, however, preferred the work at the factory to the work of domestic servants. Such women wanted to maintain their own independence and could not obey the rigid rules governing every step of the maid. The contextual analysis This attitude of female workers is verbalised in Victorian novels by lexemes with the opposite meanings of "independence" and "submission", "regulation":

Three years of independence of action [...] had little inclined her to submit to rules as to hours and associates, to regulate her dress by a mistress's ideas of propriety (Gaskell, 1994, p. 23).

Despite difficult working conditions, women's involvement in the industry became one of the steps towards emancipation, as a woman was no longer just a consumer, but also a producer. Thus, the development of the industry contributed to the destruction of stereotypes regarding female roles. The lexemes of the semantic field "independence" indicate the emancipation processes in the wake of Industrial Revolution. The job titles of women are quite limited: factory girl (Gaskell, 1994, p.4), work-girl (Gaskell, 1994, p.26), workwoman (Gaskell, 1994, p. 27).

4. Outwork. The only female professions that remained outside industry were needlewomen (seamstresses, milliners, dressmakers) and laundrywomen. "Needlework, as a symbolic representation of woman in her legitimate, domestic sphere was a frequent motif of nineteenth-century womanhood" (Mitchel, 1996, p. 185). M. Alexander states that the fictional seamstress was at the "figure of hardship and suffering" (Alexander, 2003, p. 57). The work of the seamstress is described using lexemes with the meaning of "grief", "fatigue", "poverty":

A far more correct musician than Mary might have paused with equal admiration of the really scientific knowledge with which the poor depressed-looking young needlewoman used her superb and flexile voice (Gaskell, 1994, p. 33).

I was willing and ready to marry a poor dressmaker (Gaskell, 1994, p. 130).

"Come in," said Mary, as some one knocked at the door, while she sat sadly at her sewing, trying to earn a few pence by working over hours at some mourning (Gaskell, 1994, p. 120).

[...] how she loathed the recollection of the hot summer evening, when, worn out by stitching and sewing, she had loitered homewards with weary languor (Gaskell, 1994, p. 147).

M. Alexander claims that writers "emphasised certain aspects of the condition of the seamstress to make her representative of the poor while ignoring many of those which would set her apart" (Alexander, 2003, p. 2). Thus, Victorian writers overshadow embroidery agencies and societies that played a key role in organising and systematising the female-dominated embroidery workforce, thereby granting women needleworkers new access to the business side of art (Quirk, 2016). Derogative adjectives (poor, depressedlooking) serve to encourage sympathy for women who worked at home since their status was traditionally viewed as rather low. It is worth noting that the semantic field of women engaged in outwork is wider than that of industry: dressmaker, needlewoman, under-laundry-maid (Gaskell, 1994, p. 82), washer-woman (Gaskell, 1994, p.14), milliner (Gaskell, 1994, p. 91).

5. Trade, entrepreneurship. A Victorian woman was also engaged in the trade or some other activities in which it was necessary to possess entrepreneurial skills. Only an energetic woman who was able to communicate with men on an equal basis and possessed such qualities as practicality and self-confidence was capable of entrepreneurial activity:

Had Mrs. Sedley been a woman of energy, she would have exerted it after her husband's ruin, and, occupying a large house, would have taken in boarders. The broken Sedley would have acted well as the boarding-house landlady's husband (Thackeray, 1994, p. 369).

Victorian novelists tend to depict women as "amateur, marginal, and failed participants in nineteenthcentury economic thought". [...] Despite their reputations as innately domestic "angels," women in Victorian fiction often prove poor economists in the home as well" (Dobbins, 2016, p. 741).

The novels provide limited information about women entrepreneurs, while studies of the Victorian era confirm the fact of women's employment in such spheres as trade and even in such non-traditional for those 
times fields as dentistry and bookkeeping (Gordon, 2003). Despite this, a woman who had entrepreneurial skills was often forced to turn into an adventurer or even a criminal, as Rebecca Sharp:

Rebecca's object in her journey to London was to effect a kind of compromise with her husband's numerous creditors, and by offering them a dividend of ninepence or a shilling in the pound, to secure a return for him into his own country. It does not become us to trace the steps which she took in the conduct of this most difficult negotiation; but, having shown them to their satisfaction that the sum which she was empowered to offer was all her husband's available capital (Thackeray, 1994, p. 351).

The contextual analysis did not reveal any typical lexemes referring to the semantic field "Trade, entrepreneurship", thus demonstrating that Victorian female entrepreneurs were limited in number and subjected to cultural bias. Of special interest, however, are job titles of Victorian businesswomen: applewoman (Thackeray, 1994, p. 10), market-woman (Eliot, 1994, p. 220), tart-woman (Thackeray, 1994, p. 13), tradeswoman (Hardy, 1994, p. 263), etc.

6. Agriculture. Wages in the agricultural sector were much lower than in towns. The countryman, however, who was steadily employed, had an advantage over a city dweller due to sunlight and fresh air (Priestley, 1974, p. 21). Thus, urban women are pictured with the help of epithets meaning "pale", "painful", while the appearance of rural women is described as "healthy", "flowering":

They were most of them factory girls [...] they had dark hair, neatly and classically arranged, dark eyes, but sallow complexions and irregular features (Gaskell, 1994, p.39).

$[\ldots]$ the workman loiters away his unemployed time in watching these things, and thinking of the pale, uncomplaining wife at home (Gaskell, 1994, p.).

Only two or three of the maids, Tess learnt, slept in the dairy-house besides herself [...]. They were blooming young women (Hardy, 1994, p.145).

Unlike urban women, peasants almost did not have opportunities for education and self-realisation. [...] she left school, to lend a hand at haymaking or harvesting on neighbouring farms (Hardy, 1994, p. 41).

She had hoped to be a teacher at the school, but the fates seemed to decide otherwise (Hardy, 1994, p. 55).

Rural work is described by the lexemes meaning "monotonous", "mechanical":

Nobody came near them, and their movements showed a mechanical regularity (Hardy, 1994, p. 364).

Her binding proceeds with clock-like monotony (Hardy, 1994, p. 111).

The monotony of physical work gave a woman the opportunity to plunge into the world of her own dreams, therefore peasant work is described by the vocabulary belonging to the conceptual field "dream":

Each girl sat down on her three-legged stool, her face sideways, her right cheek resting against the cow; and looked musingly along the animal's flank at Tess as she approached (Hardy, 1994, p.138).

The pensive character which the curtained hood lent to their bent heads would have reminded the observer of some early Italian conception of the two Marys (Hardy, 1994, p.364).

They worked on hour after hour, unconscious of the forlorn aspect they bore in the landscape, not thinking of the justice or injustice of their lot. Even in such a position as theirs it was possible to exist in a dream (Hardy, 1994, p.364).

But for the last few weeks a new influence had come over Hetty - vague, atmospheric, shaping itself into no self-confessed hopes or prospects, but producing a pleasant narcotic effect, making her tread the ground and go about her work in a sort of dream, unconscious of weight or effort, and showing her all things through a soft, liquid veil, as if she were living not in this solid world of brick and stone, but in a beatified world, such as the sun lights up for us in the waters (Eliot, 1994, p. 105).

The lexemes referring to the semantic field "Agriculture" reveal long-lived Victorian stereotypes regarding rural women. A peasant woman associated in the Victorian consciousness with sentimentality, dreaminess, and innocence. In the Victorian era, the difference between emancipated urban women and peasants, whose lives were still determined by the patriarchal system, increased considerably. Late Victorians, however, criticised such stereotypes as, for example, described in the novel by T. Hardy, whose hero who sought an ideal among peasant women, was disappointed when he discovered that his beloved woman did not meet this ideal:

"I thought- any man would have thought-that by giving up all ambition to win a wife with social standing, with fortune, with knowledge of the world, I should secure rustic innocence as surely as I should secure pink cheeks (Hardy, 1994, p. 304).

The job titles of peasant women are rather varied: dairymaid (Eliot, 1994, p. 245), farm-woman (Hardy, 1994, 176), field-woman (Hardy, 1994, p.111), milkmaid (Hardy, 1994, p.155). The frame analysis revealed that the typical actions performed by peasant women were associated with slavery: [...] slaved in the morning frosts and in the afternoon rains (Hardy, 1994, p. 365). 
7. Art. Victorians had ambiguous attitudes to women who wanted to fulfil themselves as artists. Being an actress meant having low social status as well as low moral qualities in the eyes of others. This is proved by the contextual analysis:

She stepped aside when Mrs. Rougemont the actress passed with her dubious family (Thackeray, 1994, p. 369).

You're as innocent as your mother, the ballet-girl, and your husband the bully (Thackeray, 1994, p. 516).

Indeed it was from this famous family, as it appears, that Miss Sharp, by the mother's side, was descended. Of course she did not say that her mother had been on the stage; it would have shocked Mr. Crawley's religious scruples (Thackeray, 1994, p. 81).

On the other hand, the actress was a woman whose talent could be duly appreciated. At the same time, the professional qualities of the actress were valued mostly by women, while men paid more attention to appearance:

I could not help remarking the effect which the magnificent actress and music produced upon Mrs. Osborne [...] the English lady's face wore such an expression of wonder and delight that it struck even little Fipps [...] (Thackeray, 1994, p. 605).

She sang. Her singing just affected me like the tricks of a conjuror: I wondered how she did it - how she made her voice run up and down, and cut such marvellous capers; but a simple Scotch melody, played by a rude street minstrel, has often moved me more deeply (Bronte, 1992, p. 283).

In a few terse phrases he told me his opinion of, and feeling towards, the actress: he judged her as a woman, not an artist: it was a branding judgment (Bronte, 1992, p. 343).

The Victorian age produced numerous woman writers. They dominated the vast novel market in Victorian England (Thompson, 1999). Despite such popularity, one of the Victorian stereotypes regarding female writers was that of a shy spinster, thus in their description derogatory adjectives prevail:

His girl was portionless and a poetess. Her writing of the song in celebration of the young baronet's birthday was thought a clever venture, bold as only your timid creatures can be bold (Meredith, 1962, p. 38).

The agents of the action frame representing female artists are such job titles as ballet-girl, opera-girl (Thackeray, 1994, p. 9), poetess, opera-dancer (Thackeray, 1994, p. 277), actress. The research revealed an ambiguous attitude to female artists, which was due to the Victorian ambivalent perception of talented women, who were admired and scorned at the same time.

\section{Conclusions}

The findings of the analysis evidence that the names of most professions (33 nominations for the analysed women's professions) contain gender-marked elements (market-woman, dairymaid, work girl, governess), indicating a clear division of labour between men and women. The most of the said nominations belong to the semantic field "Household Service", thus proving the popularity of this occupation among Victorian women, as well as the diversity of duties performed by the maid. The lexemes with negative connotations miserable, poor indicate a low social status and a financial position of the governess. Stereotypical characteristics of a factory girl are verbalised with the lexemes poor, depressed-looking, worn out, illustrating difficult working conditions. On the other hand, a woman who worked in these areas was more independent than a servant woman. In the novels, one can find only implicit indications that the female entrepreneur should possess masculine features (energy, purposefulness: woman of energy, practical woman). In Victorian consciousness, women's entrepreneurial skills are associated with adventurism and are rarely accepted by society. The work has revealed that the lexemes describing peasant women belong to the semantic field "health" (blooming, blossom-like), as opposed to a city dweller, which is described by means of lexemes pale, sallow. On the other hand, the woman who worked in the city had more opportunities for self-development and raising her educational and intellectual level (deficiency of sense, acuteness and intelligence of countenance), which distinguished her from the peasant whose work is described with lexemes meaning "monotony" (clock-like monotony, mechanical regularity). In Victorian novels, a peasant woman is pictured as a dreamer immersed in the world of her own fantasies (exist in a dream), while the factory worker is more active, independent and emancipated. It illustrates the connection between emancipation trends and the urbanisation of the British Society of the nineteenth century.

It is important to note that the Victorian novels do not provide a complete picture of working women in the Victorian era. The authors tend to picture traditional female occupations while setting aside a number of less typical professional spheres such as, for example, medicine or even politics. Thus, the analysed texts allow us to obtain data concerning the basic Victorian stereotypes of working women and femininity in 
general. Future studies are therefore required to examine non-stereotypical manifestations of Victorian femininity and of working women in particular.

\section{References:}

Alexander, L.A. (2003). Women, Work, and Representation: Needlewomen in Victorian Art and Literature. Athens: Ohio Univ. Press.

Brontë, Ch. (1992). Villette. London: David Campbell Publ. Ltd.

Brontë, Ch. (1994). Jane Eyre. London: Penguin Books Ltd.

Brontë, E. (1994). Wuthering Heights. London: Penguin Books Ltd.

Dalley, L.L \& Rappoport, J, (Ed.). (2013). Economic Women: Essays on Desire and Dispossession in Nineteenth-Century British Culture. the USA: Ohio State University Press.

Dobbins, M. (2016). Jane Eyre's Purse: Women's Queer Economic Desire in the Victorian Novel. Victorian Literature and Culture, 44(4), 741-759. https://doi.org/10.1017/S1060150316000206

Eliot, G. (1994). Adam Bede. London: Penguin Books Ltd.

Gaskell, E. (1994). Mary Barton. London: Penguin Books Ltd.

Gilbert S.M. \& Gubar S. (1984) The Madwoman in the Attic: The Woman Writer and the 19th c. Imagination. New Haven; Lnd: Yale U.P.

Gordon E. \& Nair G. (2003). Public Lives: Women, Family and Society in Victorian Britain. New Haven, London: Yale Univ. Press.

Hardy, T. (1994.) Tess of the d'Urbervilles. London: Penguin Books Ltd.

Meredith, G. (1962). The Egoist. Moscow: Foreign Languages Publ. House.

Mitchell, R. (1996). A Stitch in Time?: Women, Needlework, and the Making of History in Victorian Britain. Journal of Victorian Culture, 1(2), 185-202. https://doi.org/10.1080/13555509609505923

Neff, W. F. (1966). An Historical and Literary Study of Women in British Industries and Professions, 1832-1850. London: Frank Cass \& Co Ltd. (Original work published 1929).

Nyborg, E. (2017). 'A Just and Liberal Landlord': Manliness, Work, and the Landed Gentleman in the Brontës' Novels. Journal of Victorian Culture , 22(3), 362-379. https://doi.org/10.1080/13555502.2017.1302894

Peterson, M. J. (1984). No Angels in the House: The Victorian Myth and the Paget Women. The American Historical Review, 89(3), 677 - 708. https://doi.org/10.1086/ahr/89.3.677

Priestley, J. B. (1974). Victoria's Heyday. London: Penguin Books.

Quirk, M. (2016). Stitching professionalism: female-run embroidery agencies and the provision of artistic work for women, 1870 1900. Journal of Victorian Culture , 21(2), 184-204. https://doi.org/10.1080/13555502.2015.1132754

Rappoport, J. (2016). Greed, Generosity, and Other Problems with Unmarried Women's Property. Victorian Studies, 58(4), 636-660. Retrieved from http://muse.jhu.edu/article/642642

Richardson, S. (2013). The Political Worlds of Women: Gender and Politics in Nineteenth Century Britain, London and New York. Great Britain: Routledge.

Thackeray, W. M. (1994). Vanity Fair. London: Penguin Books Ltd.

Thompson, N. D. (1999). Victorian Women Writers and the Woman Question. Great Britain: Cambridge University Press

Wagner, T. S. (2017). The Sensational Victorian Nursery: Mrs Henry Wood's Parenting Advice. Victorian Literature and Culture, 45(4), 801-819. https://doi.org/10.1017/S1060150317000225

Zhabotynska, S.A. (2010). Principles of building conceptual models for thesaurus dictionaries. Cognition, communication, discourse. International On-line journal, 1, 75-92. Retrieved from http://sites.google.com/site/cognitiondiscourse/vypusk-no1-2010 